\title{
Editorial: Flank dynamics, sector collapses, lahars, and rockfalls: analysis, monitoring, and modelling of small to large scale volcanic slope instability
}

\author{
Federico Di Traglia' ${ }^{1}$ - Matteo Roverato ${ }^{2} \cdot$ Alessandro Bonforte $^{3} \cdot$ Felix Gross $^{4}$
}

Received: 31 August 2020 / Accepted: 2 September 2020 / Published online: 6 October 2020

(c) Geologische Vereinigung e.V. (GV) 2020

Slope dynamics in volcanic environments comprise a wide spectrum of phenomena, from large lateral collapse to shallow debris remobilization, which may represent a major threat for human communities and infrastructures. Many volcanos built up from the ocean floor and large portions of the volcano edifice are submerged. In these settings, only the edifice's summit can be investigated by terrestrial remote sensing and in-situ approaches. Growth and destruction, including tectonics and gravitational phenomena, affect entire volcano flanks and are not limited to the physical boundary of the sea level but could comprise their subaqueous parts (Urlaub et al. 2018).

Slope instability is a major hazard to local communities and the environment. It affects populations and infrastructure either directly from rockfalls, flows, and avalanches, or through cascading hazards like earthquakes (e.g., Kilauea in 2018, Chen et al. 2019), lateral blasts (e.g., Bezymianny in 1956, Mount St Helens in 1980, and Soufrière Hills in

Federico Di Traglia

federico.ditraglia@unifi.it

Matteo Roverato

matteo.roverato@unige.ch

Alessandro Bonforte

alessandro.bonforte@ingv.it

Felix Gross

felix.gross@ifg.uni-kiel.de

1 Dipartimento di Scienze Della Terra, Università Degli Studi di Firenze, Via La Pira 4, 50121 Firenze, Italy

2 Department of Earth Sciences, University of Geneva, 13, Rue des Maraîchers, 1205 Geneva, Switzerland

3 Osservatorio Etneo, Istituto Nazionale di Geofisica e Vulcanologia- Sezione di Catania, Piazza Roma 2, 95125 Catania, Italy

4 Christian-Albrechts-Universität zu Kiel, Center for Ocean and Society/Institut für Geowissenschaften, Olshausenstr. 40, D-24118 Kiel, Germany
1997, Belousov et al. 2007), lahars (e.g., Mount St. Helens after the 1980 eruption, Siebert 1984; Major et al. 2000), and tsunamis (e.g., Unzen-Mayuyama in 1792, Sassa et al. 2016; Stromboli in 2002, Bonaccorso et al. 2003; Anak Krakatau in 2018; Grilli et al. 2019; Ye et al. 2020). Since coastal population is increasing globally, hazards from tsunamigenic landslides are expected to further grow in the future. Volcano slope instability has a direct impact on land use, considering the presence of volcanoes that can potentially experience flank-failure inducing also widespread ashfalls and landslides-induced tsunamis in areas where human activities are concentrated.

Volcano slope instability is defined as the condition within a volcanic edifice that destabilizes to a degree sufficient enough to increase the likelihood of structural failure of all or portions of the edifice (Siebert 1996; Voight and Elsworth 1997; de Vries and Davies 2015). Large-scale volcanic edifice collapses have been identified at more than 400 Quaternary volcanoes worldwide, with a global frequency of five large-scale edifice failures per century (Siebert 1984; Dufresne et al. 2020; Siebert and Roverato 2020). Shallower mass movements such as gravel slides or rock falls tend to be more frequent (days-years), have a smaller volume $\left(<10^{6} \mathrm{~m}^{3}\right)$, and smaller impacted areas, whereas larger and less frequent (tens to hundreds of years) landslides $\left(>10^{6} \mathrm{~m}^{3}\right)$ such as rock slides or debris avalanches typically have deeper-seated failure planes and they can travel longer distances, resulting in larger impacted areas (Sosio et al. 2012). Large-scale landslides on volcanic edifices usually comprises two endmembers: volcanic debris avalanches (VDAs), being a sudden single catastrophic event, and slumps, reflecting progressive slope failure (Blahůt et al. 2019). The latter affects volcano with persistent flanks motion and flank deformation (Okubo 2004; Hildenbrand et al. 2012) (Table 1).

Since volcanoes can be affected by steady and/or consistent flank dynamics as creep and/or shallow slope 
Table 1 Descriptions and characteristic volume ranges of different volcano slope instability phenomena (modified after Schaefer et al. 2019)

\begin{tabular}{|c|c|c|}
\hline Category & Volume & Description \\
\hline $\begin{array}{l}\text { Deep-seated slope deformations evolving into debris } \\
\text { avalanches }\end{array}$ & $>10^{7} \mathrm{~m}^{3}$ & $\begin{array}{l}\text { Large-scale deformation of an unstable volcano flank, } \\
\text { manifested by scarps, benches, cracks, trenches and } \\
\text { bulges, but may lack a fully defined rupture surface } \\
\text { Evolving into extremely rapid, massive, flow-like } \\
\text { motion of fragmented rock and volcaniclastics }\end{array}$ \\
\hline $\begin{array}{l}\text { Rock (rotational or planar) slide evolving into rock } \\
\text { avalanches }\end{array}$ & $\approx 10^{6}-10^{8} \mathrm{~m}^{3}$ & $\begin{array}{l}\text { Sliding of a mass of rock on a rotational or planar } \\
\text { rupture surface that is not structurally controlled } \\
\text { Evolving into extremely rapid, massive, flow-like } \\
\text { motion of fragmented rock }\end{array}$ \\
\hline Rock fall evolving into dry gravel/debris flows & $<10^{6} \mathrm{~m}^{3}$ (typically $<10^{5} \mathrm{~m}^{3}$ ) & $\begin{array}{l}\text { Detachment, fall, rolling, and bouncing of rock } \\
\text { Evolving into (generally) rapid flow-like movement of } \\
\text { loose, dry, sorted or unsorted granular material, and } \\
\text { without excess pore pressure }\end{array}$ \\
\hline Gravel/debris slide evolving into dry gravel/debris flows & $<10^{6} \mathrm{~m}^{3}$ (typically $<10^{5} \mathrm{~m}^{3}$ ) & $\begin{array}{l}\text { Sliding of a mass of granular material on a shallow, } \\
\text { planar surface } \\
\text { Evolving into (generally) rapid flow-like movement of } \\
\text { loose dry, sorted or unsorted granular material, and } \\
\text { without excess pore pressure }\end{array}$ \\
\hline
\end{tabular}

Terminology based on classifications from Hungr et al. (2014)

processes (material erosion and remobilization), flank movement can be categorized as:

(i) Persistent flank motion, typically deep-seated, steady-state movement of large sectors of a volcano edifice due to interaction between gravity and magma dynamics (Poland et al. 2017), sometimes referred to as "volcanic spreading" (Borgia et al. 1992; Merle and Borgia 1996);

(ii) Transient flank motion (i.e. flank "unrest"), considered the precursor to catastrophic collapses, associated with intrusive processes, co-eruptive deformation, seismic shaking, or other relatively rapid increases in shear stress (de Vries and Davies 2015);

(iii) Surficial slope motion, or shallow motion such as material erosion and remobilization of volcaniclastic and lava material (Schaefer et al. 2019).

In general, failures controlled by shear forces (e.g., slides) have a limit equilibrium condition between the shear stress $(\tau)$ and the shear strength $(s)$ : namely the factor of safety $F=s /$. (Reid et al. 2000; Schaefer et al. 2019). The shear strength $s$ is defined by the Coulomb-Terzaghi failure rule $s=c+\left(\sigma_{n}-u\right) \tan \varphi$, where $c$ is cohesion, $\sigma_{n}$ is the normal stress, $u$ is the pore-water pressure acting on the shear surface, and $\phi$ is the angle of internal friction. An increase in the shear stress (e.g., from slope over-steepening, dynamic loading from dike intrusion or seismic shaking) or a reduction in the shear strength (e.g., from hydrothermal alteration or increase in pore fluid pressure) can lead to a sudden drop in $F$ and abrupt acceleration of the flank of the volcano.
Slope failure may occur in response to active deformation (magma intrusion, gas overpressure, substrate spreading) or may result over a long period of time due to over-steepening, over-loading, or peripheral erosion (Fig. 1; Voight and Elsworth 1997; Reid et al. 2000, 2001; Apuani et al. 2005; Borselli et al. 2011; Schaefer et al. 2013; Roberti et al. 2018; Roverato et al. 2020). The role of magmatic intrusions is twofold, involving both driving and resisting forces (Voight and Elsworth 1997).

Primary, slope stability is diminished by magma-static and magma overpressures that accompany intrusion in instable flanks. Moreover, excess pore pressures in potential failure zones can be generated as a result of intrusionrelated mechanical or thermal straining of the rock-fluid medium, pressurized retrograde boiling in high level magma chambers, or hydrothermal fluid circulation (Voight and Elsworth 1997; Bonaccorso et al. 2010; Borselli et al. 2011; Harris et al. 2012). In addition, tectonic activity can generate earthquakes that may aid slope instability through inertial forces and shaking-induced pore pressure generation, reducing the sliding resistance. The destabilizing influence of mechanically induced pore pressures is maximized as the intruded width, or corresponding overpressure, of the intrusion is increased. The destabilizing influence of thermally induced pore pressures is conditioned by the severity of thermal forcing, ratios of thermal and hydraulic diffusivities, and the time required for the fluid pressure disturbance to propagate outwards from the intrusion. Failure initiation does not imply sustained failure; in some cases, enhancement of pore pressures through deviatoric shearing, frictional heating, or run-out over compressible 


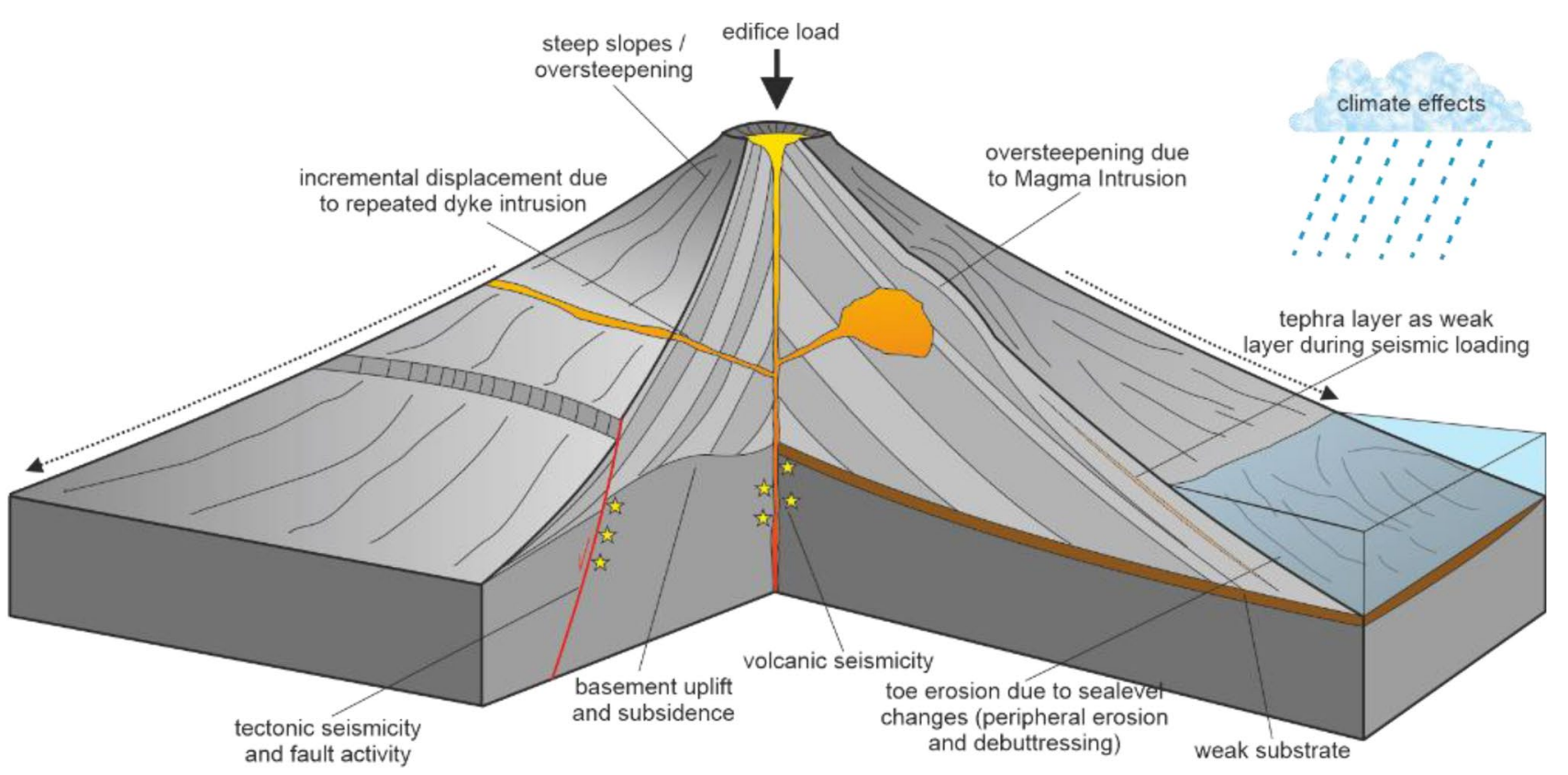

Fig. 1 Preconditioning, triggers and drivers of flank instability

saturated alluvium or marine sediments may be necessary following slide initiation to maintain the impetus of flank failure for long run-out (Voight and Elsworth 1997).

The interpretation and evaluation of such events is challenged by the complex and evolving interactions of tectonic, magmatic, fluid, and gravitational processes. The moving masses can behave in different ways depending on the depth of the detachment, water content and flow rheology and can demonstrate different modes from deep flank spreading or collapse to shallow granular or viscous flows. Water plays an important role in the transport and emplacement mechanisms of flows, enhancing their run-out and destructive power, as well as the pore pressure can increase favour the failure on local faults and deep detachment layers. Many volcanoes worldwide are located in tropical, high-precipitation environments or are covered by snow or glaciers, which exacerbates the potential for landslides, lahars and debris avalanches. In many cases, volcano flanks continue below sea level and are often affected by terrestrial volcano built-up and activity. Hence, subaqueous volcano flanks can be prone to mass wasting and consecutive tsunamis. A holistic understanding of flank dynamics and its consequences is therefore essential for the establishment of disaster risk reduction measures in volcanic and peri-volcanic environments.

The four papers belonging to this Special Issue present an updated general overview of the progress in volcanic slope instability analysis, monitoring, and modelling from multi-disciplinary efforts, from slope to edifice and regional scale. The topics discussed range from the geological/ volcanological evolution of a Quaternary silicic volcanic complex (Shiribetsu) in Japan (Goto et al. 2020), the analysis of two very famous case studies for tsunamigenic landslides at Stromboli (Italy; Casalbore et al. 2020) and Ritter island (Papua Nuova Guinea, Karstens et al. 2020), to studies of grain-size distribution and sedimentological features of volcaniclastic mass flows (Makris et al. 2020).

Goto et al. described the geology and eruptive history of the Shiribetsu Quaternary silicic volcanic complex in Hokkaido (Japan). In this area, the authors recognized a debris avalanche deposit generated by a sector collapse occurred at West Shiribetsu at 50-60 ka.

Casalbore et al. analysed the role of different triggering mechanisms in controlling the occurrence and size of submarine slope failures at Stromboli, based on the integration of 11 years (2002-2013) of morpho-bathymetric data, comprising the 30th December 2002 tsunamigenic landslides.

Karstens et al. presented 3D seismic interpretations and sedimentological analyses of Ritter Island, highlighting both the deformations that occurred before the 1888 volcanic sector collapse and the different phases of the collapse itself. These data were used to reconstruct the landslide-induced tsunami and the new results are in agreement with historic eyewitness accounts.

The study of Makris et al. is based on the review of the grain-size distribution and sedimentological features of nine volcanic debris avalanche deposits and eight lahar deposits. The evidence of particles comminution in debris avalanches deposits support previous studies suggesting that the percentage of large proportions of fine particles, remains a valid candidate factor for their high mobility. 


\section{References}

Apuani T, Corazzato C, Cancelli A, Tibaldi A (2005) Stability of a collapsing volcano (Stromboli, Italy): limit equilibrium analysis and numerical modelling. J Volcanol Geoth Res 144(1-4):191-210

Belousov A, Voight B, Belousova M (2007) Directed blasts and blastgenerated pyroclastic density currents: a comparison of the Bezymianny 1956, Mount St Helens 1980, and Soufrière Hills, Montserrat 1997 eruptions and deposits. Bull Volcanol 69(7):701

Blahůt J, Balek J, Klimeš J, Rowberry M, Kusák M, Kalina J (2019) A comprehensive global database of giant landslides on volcanic islands. Landslides 16(10):2045-2052

Bonaccorso A, Calvari S, Garfí G, Lodato L, Patanè D (2003) Dynamics of the December 2002 flank failure and tsunami at Stromboli volcano inferred by volcanological and geophysical observations. Geophys Res Lett 30(18). https://doi.org/10.1029/2003GL017702

Bonaccorso A, Bonforte A, Gambino S (2010) Thermal expansioncontraction and slope instability of a fumarole field inferred from geodetic measurements at Vulcano. Bull Volcanol. https://doi. org/10.1007/s00445-010-0366-7

Borgia A (1994) Dynamic basis of volcanic spreading. J Geophys Res Solid Earth 99(B9):17791-17804

Borselli L, Capra L, Sarocchi D, De la Cruz-Reyna S (2011) Flank collapse scenarios at Volcán de Colima, Mexico: a relative instability analysis. J Volcanol Geoth Res 208(1-2):51-65

Casalbore D, Passeri F, Tommasi P, Verrucci L, Bosman A, Romagnoli C, Chiocci FL (2020) Small-scale slope instability on the submarine flanks of insular volcanoes: the case-study of the Sciara del Fuoco slope (Stromboli). Int J Earth Sci. https://doi.org/10.1007/s0053 1-020-01853-5

Chen K, Smith JD, Avouac JP, Liu Z, Song YT, Gualandi A (2019) Triggering of the MW 72 Hawaii earthquake of 4 May 2018 by a dike intrusion. Geophys Res Lett 46(5):2503-2510

De Vries BVW, Davies T (2015) Landslides, debris avalanches, and volcanic gravitational deformation. In The encyclopedia of volcanoes Academic Press, pp 665-685

Dufresne A, Siebert L, Bernard B (2020) Distribution and geometric parameters of volcanic debris avalanche deposits. In: Roverato M, Dufresne A, Procter J (eds) Volcanic Dedris Avalanches: From Collapse to Hazard, Advances in Volcanology. Springer, London

Grilli ST, Tappin DR, Carey S, Watt SF, Ward SN, Grilli AR, Engwell SL, Zhang C, Kirby JT, Schambach L, Muin M (2019) Modelling of the tsunami from the December 22, 2018 lateral collapse of Anak Krakatau volcano in the Sunda Straits, Indonesia. Scientific reports 9(1):1-13

Goto Y, Miyoshi M, Danhara T, Tomiya A (2020) Evolution of the Quaternary silicic volcanic complex of Shiribetsu, Hokkaido, Japan: an example of ignimbrite shield volcanoes in an island arc setting. Int J Earth Sci. https://doi.org/10.1007/s00531-020-01906-9

Harris A, Alparone S, Bonforte A, Dehn J, Gambino S, Lodato L, Spampinato L (2012) Vent temperature trends at the Vulcano Fossa fumarole field: the role of permeability. Bull Volcanol 74(6):12931311. https://doi.org/10.1007/s00445-012-0593-1

Hildenbrand A, Marques FO, Catalão J, Catita CMS, Costa ACG (2012) Large-scale active slump of the southeastern flank of Pico Island. Azores Geol 40(10):939-942

Hungr O, Leroueil S, Picarelli L (2014) The Varnes classification of landslide types, an update. Landslides 11(2):167-194

Karstens J, Kelfoun K, Watt SF, Berndt C (2020) Combining 3D seismics, eyewitness accounts and numerical simulations to reconstruct the 1888 Ritter Island sector collapse and tsunami. Int J Earth Sci. https ://doi.org/10.1007/s00531-020-01854-4

Major JJ, Pierson TC, Dinehart RL, Costa JE (2000) Sediment yield following severe volcanic disturbance-a two-decade perspective from Mount St. Helens. Geol 28(9):819-822
Makris S, Manzella I, Cole P, Roverato M (2020) Grain size distribution and sedimentology in volcanic mass-wasting flows: implications for propagation and mobility. Int J Earth Sci. https://doi.org/10.1007/ s00531-020-01907-8

Merle O, Borgia A (1996) Scaled experiments of volcanic spreading. J Geophys Res Solid Earth 101(B6):13805-13817

Okubo CH (2004) Rock mass strength and slope stability of the Hilina slump, Kīlauea volcano, Hawai'i. J Volcanol Geoth Res 138(1-2):43-76

Poland MP, Peltier A, Bonforte A, Puglisi G (2017) The spectrum of persistent volcanic flank instability: a review and proposed framework based on Kīlauea, Piton de la Fournaise, and Etna. J Volcanol Geoth Res 339:63-80

Reid ME, Christian SB, Brien DL (2000) Gravitational stability of threedimensional stratovolcano edifices. J Geophys Res Solid Earth 105(B3):6043-6056

Reid ME, Sisson TW, Brien DL (2001) Volcano collapse promoted by hydrothermal alteration and edifice shape, Mount Rainier. Washington Geol 29(9):779-782

Roberti G, Ward B, de Vries BVW, Friele P, Perotti L, Clague JJ, Giardino M (2018) Precursory slope distress prior to the 2010 Mount Meager landslide. Br Colum Landslides 15(4):637-647

Roverato M, Di Traglia F, Procter J, Paguican EMR, Dufresne A (2020) Factors contributing to volcano lateral collapse. In: Roverato M, Dufresne A, Procter J (eds) Volcanic Debris Avalanches: from Collapse to Hazard. Springer Book Series Advances in Volcanology, London

Sassa K, Dang K, Yanagisawa H, He B (2016) A new landslideinduced tsunami simulation model and its application to the 1792 Unzen-Mayuyama landslide-and-tsunami disaster. Landslides 13(6): 1405-1419

Schaefer LN, Oommen T, Corazzato C, Tibaldi A, Escobar-Wolf R, Rose WI (2013) An integrated field-numerical approach to assess slope stability hazards at volcanoes: the example of Pacaya. Guatemala Bull Volcanol 75(6):720

Schaefer LN, Di Traglia F, Chaussard E, Lu Z, Nolesini T, Casagli N (2019) Monitoring volcano slope instability with synthetic Aperture Radar: a review and new data from Pacaya (Guatemala) and Stromboli (Italy) volcanoes. Earth Sci Rev 192:236-257

Siebert L (1984) Large volcanic debris avalanches: characteristics of source areas, deposits, and associated eruptions. J Volcanol Geoth Res 22(3-4): 163-197

Siebert L (1996) Hazards of large volcanic debris avalanches and associated eruptive phenomena. In Monitoring and mitigation of volcano hazards, Springer, Berlin, Heidelberg

Siebert L, Roverato M (2020) A historical perspective on lateral collapse and debris avalanches. In: Roverato M, Dufresne A, Procter J (eds) Volcanic Dedris Avalanches: From Collapse to Hazard, Advances in Volcanology. Springer, London

Sosio R, Crosta GB, Hungr O (2012) Numerical modeling of debris avalanche propagation from collapse of volcanic edifices. Landslides 9(3):315-334

Urlaub M, Petersen F, Gross F, Bonforte A, Puglisi G, Guglielmino F, Krastel S, Lange D, Kopp H (2018) Gravitational collapse of Mount Etna's southeastern flank. Science Adv 4(10):eaat9700. https://doi. org/10.1126/sciadv.aat 9700

Voight B, Elsworth D (1997) Failure of volcano slopes. Geotechnique 47(1):1-31

Vries VWD, Davies BT (2015) Landslides, debris avalanches, and volcanic gravitational deformation. Academic Press, Newyork

Ye L, Kanamori H, Rivera L, Lay T, Zhou Y, Sianipar D, Satake K (2020) The 22 December 2018 tsunami from flank collapse of Anak Krakatau volcano during eruption. Sci Adv 6(3):eaaz377 